\title{
GENERATIONAL DIFFERENCES IN INVOLVEMENT OF FAMILY MEMBERS IN GOVERNANCE AND MANAGEMENT OF TURKISH FAMILY BUSINESS GROUPS AND BACKGROUND CHARACTERISTICS OF FAMILY MEMBERS
}

\author{
ÖZLEM YILDIRIM-ÖKTEM
}

Boğaziçi University

\begin{abstract}
The paper explores the involvement of family members from different generations at various levels and functions of Turkish family business groups as well as their educational background and international experience. The sample is composed of 57 family members who are involved in eight prominent family business groups in 2008. The results show that a higher percentage of the old generation family members hold directorship positions at the holding board and at listed affiliates while a higher percentage of the young generation family members have executive positions at the affiliates. With their pervasive involvement at both holding company and affiliate levels in boards and executive positions, owner families seem to both rule and manage the family business groups. The results also show that in both the older and the younger FBGs, the younger generation family members have significantly higher levels of education and international experience.
\end{abstract}

Key words: Turkish family business groups, governance, family members, generational differences.

\section{TÜRK AIILE ISSLETME GRUPLARINDA FARKLI NESILL AILEE ÜYELERINIIN YÖNETIME KATILIMLARI VE ÖZGEÇMIŞ ÖZELLIKLERI}

\begin{abstract}
ÖZET
Araştırma, Türk aile işletme gruplarında farklı nesil aile üyelerinin işletmenin farklı seviye ve fonksiyonlarında yönetime katılımları ile eğitim ve uluslararası tecrübelerini incelemeyi amaçlamaktadır. Örnekleme, 2008 yılında Türkiye'deki en büyük sekiz aile işletme grubunun yönetiminde yer alan 57 aile üyesi dahil edilmiştir. Sonuçlar yaşlı nesil aile üyelerinin genç nesile kıyasla daha büyük bir yüzdesinin holdingin ve halka açık bă̆ll şirketlerinin yönetim kurullarında bulunduğunu, buna karşıllk genç nesil aile üyelerinin daha büyük bir yüzdesinin bağlı şirketlerde icracı görevlerde bulunduğunu göstermektedir. Sahip ailelerin, aile işletme gruplarını holding ve bağll şirket seviyelerinde yaygın bir katılımla yönettikleri görülmektedir. Sonuçlar hem yaşlı hem genç aile işletme gruplarında genç nesil aile üyelerinin istatistiksel olarak daha yüksek eğitim seviyesine ve daha fazla uluslararası tecrübeye sahip oldukların göstermektedir.
\end{abstract}

Anahtar sözcükler: Türk aile işletme grupları, yönetişim, aile üyeleri, nesil farklılıkları.

* Özlem Yıldırım-Öktem is an Assistant Professor in the Department of International Trade at Boğaziçi University, 34342, Bebek, Istanbul, Turkey. E-mail: ozlem.yildirim1@boun.edu.tr 
Interest in family business studies has been increasing (Sharma, 2004). Family businesses are important economic actors both in developed countries (Miller and Le Breton-Miller, 2005) and in emerging economies (Khanna and Yafeh, 2007). Outside the Anglo-Saxon context, large corporations except state-owned enterprises are mostly owned by a single family or a small number of families (Morck et al., 2005). Business groups are the main form of managing these large and family-owned business organizations (Yiu et al., 2007).

Business groups are defined as "sets of legally independent firms bound together in persistent formal and/or informal ways" (Granovetter, 1995: 95) and are the dominant form of organizing in emerging economies (Fisman and Khanna, 2004; Kim, 2004). The main characteristics of business groups are family control, diversification and centralized decision making (Chung and Luo, 2008; Hamilton and Biggart, 1988). In contrast to the transition to professional enterprise in the Chandlerian firm (1977), this form of large organization has remained family owned and managed despite its large size. The form's reliance on social and kinship relations, and on coordination among member firms by a common administrative and financial control differentiate business groups from other organizational forms such as large U.S. conglomerates and the network form (Yiu et al., 2007).

Groups around the world vary in their extent of diversification, vertical integration, and involvement in the financial sector (Khanna and Yafeh, 2007). Examples of diversified business groups are the Korean chaebols, the Indian business houses, the Turkish family holdings, and the Latin American grupos (Guillen, 2000). In diversified family business groups (FBGs), usually a single family or two families have control over the group through mechanisms such as a pyramidal ownership structure, headquarters of the business group, placing the family members or trusted managers at key positions, holding multiple directorships within the group, and the professionalization of the young generation family members (Buğra, 1994; Khanna and Yafeh, 2007; Morck et al., 2005).

Although the centrality of the family is an important characteristic of governance in FBGs (Carney, 2008), its implications have been limited to general observations and theoretical conjectures (Üsdiken, 2010). There are a few empirical studies that focus on the family aspect of governance in the South Korean chaebol (e.g. Chung and Luo, 2008; Shin and Chin, 1989). Group control mechanisms for the family such as pyramidal ownership structure or holding multiple directorships within the group were also mentioned in studies in other disciplines such as political science and economics (e.g. Buğra, 1994; Khanna and Yafeh, 2007; Morck et al., 2005). A limited number of empirical studies on the governance of FBGs have also been conducted in the Turkish context where interest in FBGs as an organizational form and its governance appeared in the 2000s (Üsdiken, 2008). In these studies, family control and the extent of professionalization of management was operationalized as the proportion of non-kin executives in the holding headquarters and/or the proportion of non-kin insider managers and outsiders in holding and affiliate boards (e.g. Çolpan, 2010; Gökşen and Üsdiken, 2001; SeleklerGökşen and Yıldırım-Öktem, 2009; Üsdiken and Yıldırım-Öktem, 2008; Yıldırım-Öktem and Üsdiken, 2010). However, there is no empirical research that focuses exclusively on the owner families of the biggest Turkish FBGs and that considers generational differences among family members in exploring how the control of such a large and diversified organizational form is shared between family members.

This article aims to explore generational differences in family members' involvement in governance and management at different levels and functions of the family business group as well as their educational background and international experience. Turkish family business group as an organizational form, defined in this paper as a large and diversified group of firms owned and managed by one or two 
families for at least two generations, provides an opportune setting to analyze the pervasive involvement of family members in the governance and management of the FBG. In the Turkish economy, as in many others, there have been normative pressures for corporate governance reforms that call for replacing family members with professional managers (Selekler-Gökşen and Yıldırım-Öktem, 2009). The family involvement in Turkish FBGs is therefore likely to reflect not only intra-group power issues and different resources possessed by family members, but also the families' concern to maintain intergenerational continuity of the business by continuing to rule and manage the group with its own members.

The structure of the paper is as follows: The next section presents the literature background for power distribution in business groups, generational differences in involvement of family members in the governance and management of the group and background characteristics of family members. This is followed by the section on findings. The paper concludes with a discussion of findings and suggestions for future research.

\section{LITERATURE BACKGROUND}

In the governance of large and vertically integrated FBGs, the centrality of the family is an important feature, and non-kin executives within the group have little power (Carney, 2008; Çolpan, 2010). The literature suggests that despite changes in the institutional environments of emerging economies, there has been a limited increase in professionalization of management though this is mostly confined to large group firms that are listed abroad (Üsdiken, 2010). The non-kin managers who could enter into the "inner circles" are those who are trusted by the family due to their long tenure within the group and are almost considered part of the family (Lee and Yoo, 1987; Yıldırım and Üsdiken, 2005). An increase in the proportion of non-kin managers, however, does not necessarily indicate their empowerment. In the South Korean chaebol for example even senior non-kin managers can be moved around or dismissed easily by the group's president who is always a family member (Carney, 2008). In the Turkish FBGs, interviews with board members suggested that the role of the non-kin Chief Executive Officers (CEOs) was to represent the family, and the real CEOs of the group were the chairpersons of the holding boards (Çolpan, 2010) who were found to be invariably family members for the ten largest Turkish FBGs (Yıldırım-Öktem and Üsdiken, 2010). Interviews with the executives also suggested that since the family was the majority shareholder it was the voice of the founding family that was followed by the holding boards, and in several cases there were unofficial family working groups that did the strategic planning for the groups (Çolpan, 2010).

In addition to concentrations of strategic and financial decisions in the hands of family members (Carney, 2008), the family sometimes intervenes in operational decisions of the group and its affiliate firms (Aulakh and Katobe, 2008; Çolpan, 2010). In one Turkish group, for example, the family members who previously held executive positions in the group still visit the affiliated companies on a regular basis (Çolpan, 2010). In FBGs, due to the way the family is involved in the governance and management of the group, a distinction between ownership control, family rule and management is not always clear (Shin, 1998).

Among the four power dimensions of Finkelstein (1992), the family is likely to have more ownership and structural power than non-kin insider managers and outsiders, whereas expertise and prestige dimensions of power may be relatively more contested terrains. To sustain intergenerational continuity of the family business, the family is likely to invest also in the latter dimensions by providing new 
generation family members with good formal education, international experience, work experience outside the group and apprenticeship in the headquarters of the group or its affiliates.

Ownership power is derived from two sources, being the founder or a relative of the founder as it increases interaction with other important firm constituents and from the ability to affect key firm decisions in an ownership capacity (Finkelstein, 1992). Turkish FBGs were founded with complete control in the hands of a single or small number of families (Khanna and Yafeh, 2007). The family as the majority shareholder through direct or indirect ownership ties with the business group has more ownership power than non-kin executives. Turkish FBGs are vertically integrated with pyramidal ownership structures (Gönenç et al, 2007; Yurtoğlu, 2000) and the family maintains its control over the entire organization through the holding company that owns and controls the affiliated companies (Buğra, 1994; Çolpan, 2010). Families have a tendency to retain the ownership control in their own hands. In a majority of the Turkish FBGs, the holding company is not listed on the stock exchange; when it is listed, the founding family is still the majority shareholder. Through direct and indirect shares, the family maintains the majority ownership also in the affiliated companies, only a small percentage of which are listed on the stock exchange and/or are mainly owned by a partner firm (Yıldırım-Öktem and Üsdiken, 2010).

Structural power, which is also called hierarchical or legitimate power (Hambrick, 1981), is captured in one's formal position within the organization and can be measured by the number of titles that he/ she has (Finkelstein, 1992). In FBGs, the family has more structural power than non-kin executives because it occupies key positions on the group board and in the headquarters and holds multiple directorships in the group affiliates. The composition of the group affiliates of Turkish FBGs is an extension of the governance structure at the group level because the boards of the majority of the affiliated firms are dominated by family members and non-kin executives working at the headquarters (Yıldırım and Üsdiken, 2005). In the holding and affiliate boards, the controlling families seem to be backed up by inner circle managers who are considered part of the family. These "trusted few" are the non-kin managers who work at the holding headquarters, hold board positions in many affiliated firms operating in different sectors and have very high tenure within the group (Üsdiken and Yildırım, 2007). Outsiders, on the other hand, are very rare in holding or affiliate boards and most of them can be considered as affiliated outsiders since they either have a prior employment relationship with the group or hold several board positions within the same group (Üsdiken and Yıldırım-Öktem, 2008). In 2004, the percentage of outsiders in the affiliates of the ten largest Turkish FBGs was only $4.6 \%$ with around 1-1.5\% who could be considered independent outsiders (Üsdiken and Yıldırım-Öktem, 2008). The families' unwillingness to share positions with the non-kin is also apparent in the board compositions of listed or partnered firms where the family representation is particularly high (Yıldırım-Öktem and Üsdiken, 2010).

Expertise and prestige dimensions of power, on the other hand, may potentially be more challenging grounds for family members. In a sample of mostly stand-alone family firms in all regions of Turkey, Yıldırım-Öktem and Yamak (2008) found that family CEOs did not score significantly higher than non-kin CEOs in the expertise and prestige dimensions of power. Experience in different areas of the organization increases expertise power because a variety of assignments adds to the breadth of contacts with elements in the firm's task environment. This breadth thereby improves the effective management of the firm's external environment (Finkelstein, 1992). It also provides a means to exert control over organizational constituents both through control of firm-specific information and through facilitating 
control over others' access to such information (Daily and Johnson, 1997). The founder's generation has the long-term experience and expertise in historical core sectors around which the business group has grown. Family members, in particular the senior generation, develop group-specific expertise by having board directorship and/or executive positions at the headquarters of the group as well as by having multiple directorships in group affiliates. This knowledge can be transferred to younger generation family members since in family firms much of the informal information exchanges occur at family gatherings outside the office. Besides, knowledge is more effectively generated and transferred when one identifies himself/herself with a collective unit (Kogut and Zander, 1992). The expertise of the senior family members in new sectors of the group and international markets, however, may be limited. It is likely that new generation family members, having international experience, work experience outside the group and apprenticeship in the headquarters of the group or its affiliates, are prepared to take roles in these new areas where the family otherwise would be forced to share control with the non-kin due to the older members' lack of expertise.

The power of prestige derives in part from the kinds of educational institutions an individual has attended. A solid background in those that are considered elite and prestigious (Daily and Johnson, 1997) conveys a cachet of superiority and thus gives the individual an extra level of influence within a coalition (Finkelstein, 1992). Non-kin executives may carry this distinction and thus challenge the family members in this dimension. However, younger generation family members are likely to have been sent to prestigous schools and been endowed with a higher level and better formal education than senior generation family members who might not have found the opportunity to invest in their educational background. This is more likely to be the case especially for the founder's generation which invested their efforts in establishing and rapidly expanding the business group. On the other hand, the younger generation family members, particularly the third generation born at a different stage of the development of the FBG, have had more favorable conditions, enabling them to attend prestigious schools. Consequently they can be more competitive with non-kin managers in this dimension.

International experience, work experience outside the group, apprenticeship within the group, higher and better formal education that enhance the expertise and prestige powers of the young generation family members may be considered ways to maintain intergenerational continuity of the family in the rule and management of the group. Qualified new generation family members can complement the expertise and experience of the elder generation and provide a balance of power against the nonkin professional whose inclusion in governance and management would be inevitable without them. Although the family has been dominant in the governance and management of family business groups (Kim et al., 2004), the expansion of business and institutional pressures demand an increasingly professional management. In the context of emerging economies where there is trust only for the kin and a few loyal managers, grooming the younger generation for the governance of the family business may be considered an alternative to empowering the non-kin insiders and outsiders.

\section{Family Involvement in the Governance and Management of Business Groups}

Among extended family members, senior generation family members are likely to have the most power. Due to their controlling interest in the group, experience, group-specific tacit knowledge, established social relationships, and psychological motivations as well as cultural reasons, a higher percentage of the old generation family members are expected to be represented in the holding board, holding headquarters and listed company boards relative to the younger generation family members who still do not possess these resources at the same level. 
The senior family members usually have more ownership power than do the young generation family members. Particularly in firms that are run by the first and the second generation family members, the ownership is usually not yet dispersed among the extended family members. Since elder generation family members have a controlling interest in the business, they can affect the key firm decisions in an ownership capacity (Finkelstein, 1992).

The elder generation family members also have more expertise power than the young generation family members because they have had more experience, entrepreneurial ability and social capital. Since the young generation family members did not participate in the founding process, they do not have the experience and the tacit knowledge of the senior generation to maintain the family business (Gilding, 2005). The senior family members, on the other hand, possess a great amount of tacit and idiosyncratic knowledge (Lee et al., 2003), which is particularly important for the success of family firms (Cabrera-Suarez et al., 2001). In family firms, valuable knowledge for the firm is usually possessed by a single family member or a few members who are closely associated with him; this increases the consolidation of power and control (Zahra et al., 2007).

Entrpreneurial ability is also usually greater for more senior generations, especially the founders' generation. Caselli and Gennaioli (2003) found that on average the entrepreneurial ability of families in oligarchic family businesses regresses toward the population mean with each successive generation.

Social capital is also likely to be possessed to a higher extent by senior family members since its accumulation requires a process. The social capital of an individual includes both internal ties and external relations, called "bonding" and "bridging" respectively (Gittell and Vidal, 1998). Nahapiet and Ghoshal (1998: 243) define social capital as "the sum of the actual and potential resources embedded within, available through, and derived from the network of relationships possessed by an individual or social unit." Establishing a network of supportive relationships is vital for the long-term continuity and success of a family business (Steier, 2001). This relational wealth is an important resource as personal transmissions have several advantages over second-hand data such as creating a better understanding of the external environment with timely and relevant information (Adler and Kwon, 2002).

The value of a social capital depends on its political and economic context (Adler and Kwon, 2002; Guillen, 2000; Hoskisson et al., 2000). In emerging economies where institutions are inadequate, firms would be more likely to develop non-market capabilities to obtain political advantage (Wan, 2005) and to develop relationship-based management to compensate for the lack of infrastructure in their environment (Hoskisson et al., 2000). Many competitive advantages in emerging economies are based on close relationships with the state. Connections with the state have played a crucial role in the emergence and growth of business groups in these economies (Dieleman and Sachs, 2008; Hundt, 2005); in some cases they continue to be important even after the liberalization of the markets (Siegel, 2007).

For Turkish FBGs, the relations with the state have always been important. Between 1923 and 1980 some groups were supported through preferential input prices, low-cost credits, foreign exchange licenses, tax rebates, import licenses, and government contracts (Khanna and Yafeh, 2007). Their diversification and internationalization were encouraged by the state. Turkish FBGs could quickly respond to opportunities arising from policy changes and enter into new businesses via suggestions by the state (Buğra, 1994; Khanna and Yafeh, 2007). This critical relationship with state bureaucrats 
has been managed by family members due both to the lack of trust and the reluctance of the family members and the state officials to share information with the non-kin (Buğra, 1994).

Establishing and maintaining relationships with bureaucrats and other outside parties such as suppliers, partners, and major customers call for considerable investment. External social capital is likely to be possessed to a higher extent by senior family members since its accumulation is a process. Senior family members are also likely to have more internal social capital than the younger generation family members due to their longer tenure and previous relationships with the employees within the group. The breadth of contacts with elements in the firm's task environment helps senior family members manage the firm's external environment effectively (Finkelstein, 1992) and provides a means of exerting control over the organizational constituents (Daily and Johnson, 1997).

Elder family members, in particular the founders, hang onto power also for psychological motives. Even though the inclusion of the new generation is what keeps the family business carrying on, some founders do not retreat from the business as they think that that their sons/daughters are not yet capable of running the business and still need some advice from the senior family members; this is termed the "founder's dependence paradox" (Garcia-Alvarez et al, 2002: 199). Moreover, in many cases, the founders became entrepreneurs in order to satisfy their need to exercise power over others and they delay retirement since that would mean letting go of their power to influence the business (Lansberg, 1988). The founders' fear of loosing control over the business is compounded by feelings such as fears of loosing an important part of one's identity, loosing the central role in the family and a change of status (Lansberg, 1988). Such feelings make senior generation family members retain their high positions in the family business. In addition, the succeeding generation provides a mechanism to endow the older family members with support and care elements that they received from them in the past (Harvey and Evans, 1995). Thus, most of the time the succeeding generation tries to preserve the high positions in the business for the older family members.

Finally, in many emerging economies, the family presence in the top positions of the business groups is institutionalized and the central positions are occupied by the elder family members with whom the real power is likely to remain due to the paternalistic culture (Chung, 2003; Chung and Luo, 2008). The number of available family members is larger for the younger generations. However, the norm of a high respect for the elderly gives the older generation more privileges and a higher status relative to the younger generations (Chung and Luo, 2008).

Based on the above arguments, the senior generation family members in both older and younger business groups are expected to exert their control over the family business, particularly through their presence in group-wide positions. They are also expected to have directorships in a higher percentage of listed companies since the presence of the "old guard" signals a strong social standing to the capital market board and minority shareholders who are relatively new actors for these family businesses.

The younger generation family members, on the other hand, are likely to occupy more managerial positions particularly in new areas where the older generation lacks expertise. Due to the concern of the elderly not to share too much control with the non-kin, the new generation family members are also expected to have novel assignments such as international duties or the management of new affiliates or divisions within the group. Such sharing of power would reflect the concern of the family for intergenerational continuity in the rule and management of the group. 


\section{Background Characteristics of Family Members}

The family is expected to provide the younger generation family members with international experience, experience in companies outside their business group, apprenticeship within the family business and higher levels of formal education at prestigious schools to enhance their expertise and prestige power, all potentially the more contested terrains between the family and the non-kin.

There are internal and external pressures that demand an increasing inclusion of the non-kin in the governance and management of the group. The growth and diversification of FBGs can be considered as internal factors that call for professionalization (Finkelstein and Hambrick, 1996; Tsui-Auch, 2004), whereas normative institutional pressures on emerging economies to professionalize the management mostly by IMF, World Bank, capital market boards, business schools, and multinational corporations can be considered as external pressures (Selekler-Gökşen and Y1ldırım-Öktem, 2009; Tsui-Auch, 2004). Families are expected to comply with the requirements of stock exchanges in order to gain legitimacy in the eyes of the regulatory authorities and their foreign partners (Tsui-Auch, 2004). However, research shows that demands for improved corporate governance are considered "quarrelsome interference" by the owning families (Jang and Kim, 2002: 103) and that families are often unable and unwilling to change (Jang and Kim, 2002). With increasing pressures to professionalize the management, the family may endow its young members with high qualifications in order to continue to concentrate power in its own hands and avoid sharing a large extent of power with the non-kin.

International experience and experience in other companies outside the group enhance expertise power since they provide the young generation family members with a new web of contacts that can help them manage new lines of businesses or new divisions more effectively. Apprenticeship within the family business in different functions of the organization can help the young members gain expertise as this facilitates learning day-to-day operations and developing social relationships. Attending elite schools, on the other hand, enhances the prestige power of the young generation family members as it may increase their influence within a coalition (Finkelstein, 1992). Among the first three generations, the founder's generation may be expected to differ from the following two generations more significantly because the younger have been groomed to take part in the governance of the group. In addition, the second and third generation family members have usually been born in bigger cities and enjoyed much better socio-economic conditions for a better education and international experience than the founder's generation who did not have the same circumstances and had to devote time and energy to the establishment and expansion the group.

The rise of a more skilled new geneneration with its high level of education and international experience is observed also in generational transitions of business groups in other countries such as Thailand and South Korea (Lee and Yoo, 1987; Suehiro, 1993). The new generation family members have higher levels of formal education, usually with graduate degrees from the U.S. or Europe (Kim, 1996; Lee and Yoo, 1987). Instead of being exposed to traditional education and commercial practices, they have learned modern concepts of management, new technologies and been part of a new network of personal relationships (Suehiro, 1993). 


\section{DATA AND METHODS}

\section{The Sample}

Business groups are the dominant economic actors in the Turkish economy (Çolpan, 2010; Gönenç et al, 2007). In 2005, out of the 50 largest economic agents in Turkey, 28 were diversified business groups (Çolpan, 2010). In 2008, around 60\% of the firms in the Istanbul Chamber of Industry's list of "Top 100 Industrial Companies of Turkey" were affiliated with a business group. The leading firms in many industries such as automotive, electronics, and the media belonged to business groups and the largest private banks were also affiliated with them.

Family businesses are most often defined based on ownership and management control (Miller and Le Breton-Miller, 2005). For a more complete definition of family business, Litz (1995) mentions the necessity of complementing these structure-based characteristics with an intention-based approach. It is defined as the family members' desire to maintain and increase managerial control and/or ownership in an organization. The involvement of the younger generations in the business is an indication of this desire and of the continuity of the family business.

Based on both structure-based and intention-based approaches, in this research a business group is considered as a family business if one or two families hold the majority ownership, the president of the holding board is a family member and at least the second generation is also involved in the business. All the business groups included in the study meet these criteria of being a family business.

Two different criteria were employed while choosing the FBGs to be included in the study. First, the FBGs in the sample had to operate in at least five industries (according to 2-digit coding of the United Nations Classification Registry) since unrelated diversification is a distinguishing characteristic of this organizational form (Guillen, 2000). This criterion also helped to eliminate small holdings that obtained the holding label because this was prestigious and fashionable (Buğra, 1994). The second criterion was the involvement of two consecutive generations in the business to allow for a crossgeneration comparison of the sample. As mentioned in the previous paragraph, the new generation's involvement also shows the intention of the family to maintain control over the business and to sustain the family character of the business. Eight family business groups met these criteria. All the FBGs in the sample are also among the 50 biggest economic actors in Turkey listed according to number of employees (Çolpan and Hikino, 2008). Table 1 provides descriptive statistics about these business groups.

The sample is composed of 57 family members who hold board memberships or executive positions at the group or affiliate level in these eight family business groups in 2008. The executive positions at the group level include being a member of the executive committee of the group, manager of a business line such as automotive, tourism, construction or manager of staff such as human resource, finance, and business development. The executive positions at the affiliate level, on the other hand, include managerial positions in an affiliate of the group or membership on the executive committee of an affiliate. 


\section{Data Collection and Method}

Data were collected mainly from the Istanbul Stock Exchange web site, internet sites that provide biographical information of business people, and annual reports of business groups and their affiliates. Additionally, the assistants of family members were contacted personally and most of them agreed to collaborate.

T-tests and non-parametric Mann-Whitney U tests were performed as the statistical analysis. All the analyses were performed at the individual level.

\section{Variables and Measures}

Studies on culture demonstrate that Turkey scores high on collectivism (Hofstede, 1994; Paşa et al, 2001). In high collectivist cultures, the family refers to a large collectivity of people, the extended family (Hofstede, 1994). Therefore, in this study the family was defined, based on Gökşen and Üsdiken (2001), as including the spouse(s), children, grandchildren and siblings of the founder(s), spouses of their children, grandchildren and siblings, nephews and nieces of the founder(s) and spouses of these nephews and nieces.

Since business groups in the sample are at different stages of development, the sample is divided into four sub-samples. In three business groups where the founder's generation and the second generation were in power, generation was coded into two categories as the first and the second generation. In the remaining five business groups that were relatively older and the founder's generation was not in power, generation was coded into two categories as the second and the third generation. Comparisons across generations are done separately for younger and older business groups ${ }^{(1)}$.

The education level was assessed by two different measures. The first measure is the number of years spent in formal education after the five-year compulsory elementary school as was also used in Yamak (1998) and Yamak and Üsdiken (2006). The second measure categorizes education level into four groups (adapted from Yıldırım-Öktem and Üsdiken, 2010): i) elementary school, ii) high school, iii) university, and iv) graduate degrees.

The study also includes the educational background because it aims to explore not only change in education level across generations, but also whether the new generation went to better schools. The educational background was also assessed with categorical measures. The type of high school education was coded into four different categories: i) high schools abroad; ii) prestigious high schools in Turkey (this category includes foreign private high schools in Turkey such as Robert College or the German High School as well as high schools founded in the late Ottoman / early Republican era such as the Galatasaray High School or the Istanbul High School for Boys, and iii) all other high schools. Undergraduate education was coded into two categories with 1 assigned to family members who obtained their undergraduate degrees abroad.

International experience was assessed by two different variables. The first one was work abroad with 1 assigned to family members who have had at least one year of full time work experience abroad. The second measure was study abroad with 1 assigned to family members who have obtained any degree abroad. 
Being an executive was coded into two categories with 1 assigned to family members who were working at the headquarters of the business group or were managers in one of the affiliates of the business group in 2008. Managing directors of the boards and members of the executive committees were also considered executives.

Board membership at the holding was also coded into two categories with 1 assigned to individuals who were members of the holding board.

The percentage of board memberships at the quoted affiliates of the business group was calculated as the number of board memberships held by a family member at the quoted affiliates of the FBG, divided by the total number of quoted affiliates of the FBG.

\section{FINDINGS}

Characteristics of the business groups that are included in the study are displayed in Table 1.

Table 1

Characteristics of the Family Business Groups as of 2008

\begin{tabular}{ccccc}
\hline Holdings & Age & Size & Generation in Power & Number of family members \\
\hline 1 & 71 & 70750 & 2 and 3 & 8 \\
2 & 66 & 51120 & 2 and 3 & 7 \\
3 & 46 & 18000 & 1 and 2 & 7 \\
4 & 49 & 20000 & 2 and 3 & 14 \\
5 & 45 & 6000 & 1 and 2 & 5 \\
6 & 55 & 6450 & 1 and 2 & 4 \\
7 & 28 & n.a. & 2 and 3 & 7 \\
8 & 66 & 36000 & 2 and 3 & 5 \\
\hline
\end{tabular}

Age is measured by subtracting the year the group established its first incorporation from 2009. The average age of the business groups in the sample is 53.25; it ranges from 28 to 71 years. The size is measured by the number of full time employees working within the group in 2008. The average size of the groups in the sample is 29,760 (excluding one case where the data were not available). On average, seven family members per group are involved in the study. In three business groups the first and second generation family members are in power. As displayed in the following tables, in the sub-sample of these relatively younger groups, there are 4 family members who belong to founder's generation and 12 family members from the second generation. The remaining five business groups, on the other hand, are run by the second and third generation family members. In this sub-sample, there are 19 family members from the second generation and 22 from the third generation. The sex of the family members in the sample is evenly distributed: $42 \%$ of the individuals are female whereas $58 \%$ of them are male. The business groups in the sample operate in various unrelated sectors ranging from construction and tourism to electronics and food. 
In terms of involvement in the business at the group level, $61 \%$ of the family members have a seat in the holding board and 53\% have executive positions at the group level. The percentage of the family members who have board membership in at least one of the affiliates of the group is quite high, $75 \%$, whereas family members on average have board membership in $22 \%$ of the quoted affiliates of the group. Additionally, $23 \%$ of the sample have executive positions in at least one of the affiliates.

In terms of educational attainment, the family members on average have a university degree, with 11.27 years of formal education after compulsory elementary school. More than one-third of the sample also have a graduate degree and among them $35 \%$ of them have obtained their graduate degrees abroad.

In terms of educational background, $67.3 \%$ of the family members have studied in prestigious high schools in Turkey and almost half of the family members, $48.1 \%$, have had undergraduate study abroad.

As for international experience, $67 \%$ of the family members have obtained one of their degrees abroad and/or worked abroad. The percentage of family members who have had work experience outside the group, on the other hand, is only $23 \%$.

Table 2 displays results for the business involvement of the family members. Table 2a includes results for the three business groups in which the first and second generations are in power. A higher percentage of second generation family members have board memberships in the holding and at least in one of the affiliates than do first generation family members. However, a higher percentage of the first generation family members are represented in listed company boards than are the second generation family members. All of the family members from the founder's generation have executive positions at the headquarters of the group whereas only half of the family members from the second generation do. Almost half of the second generation family members are executives at the affiliate level. This ratio is one-fourth for family members from the first generation.

Table 2a

Business Involvement of Family Members in Young Business Groups

\begin{tabular}{lccccc}
\hline & \multicolumn{3}{c}{ Young business groups } \\
& \multicolumn{2}{c}{$\begin{array}{c}\text { First } \\
(\mathbf{N}=\mathbf{4})\end{array}$} & \multicolumn{2}{c}{$\begin{array}{c}\text { Second } \\
\text { (N=12) }\end{array}$} \\
\cline { 2 - 5 } & Mean & s.d. & Mean & s.d. \\
\hline Board membership in the holding & .50 & .58 & .83 & .39 \\
Board position at one of the affiliates & .50 & .58 & .75 & .45 \\
Executive positions at the holding headquarters & 1 & 0 & .50 & .52 \\
Executive position in the affilliates & .25 & .50 & .42 & .52 \\
Executive at the holding or at the affiliate level & 1 & 0 & .83 & .39 \\
Percentage of board membership in quoted affiliates & .36 & .47 & .18 & .23 \\
\hline
\end{tabular}

Table $2 \mathrm{~b}$ shows t-test results for the five business groups in which the second and third generations are in power. A higher percentage of second generation family members have board memberships in 
the holding (84\%) than do the third generation family members (32\%); this difference is statistically significant. A significantly higher percentage of second generation family members (89\%) also have board memberships in at least one of the affiliates than do the third generation family members $(68 \%)$. Additionally, a significantly higher percentage of the second generation family members (34\%) have board memberships in the listed affiliates than do the third generation family members (12\%). There is no difference in the percentages of second and third generation family members who have executive positions at the central management unit of the group: $47 \%$ and 50\%, respectively. At the affiliate level, however, almost half of the third generation family members have executive positions whereas none of the second generation family members are executives in affiliate firms.

Table 2b

T-test Results for Business Involvement of Family Members in Old Business Groups

\begin{tabular}{|c|c|c|c|c|c|c|}
\hline & \multicolumn{4}{|c|}{ Old business groups } & \multirow[b]{3}{*}{$\mathbf{t}$} & \multirow[b]{3}{*}{ df } \\
\hline & \multicolumn{2}{|c|}{$\begin{array}{l}\text { Second generation } \\
(\mathrm{N}=19)\end{array}$} & \multicolumn{2}{|c|}{$\begin{array}{l}\text { Third generation } \\
\qquad(\mathrm{N}=\mathbf{2 2})\end{array}$} & & \\
\hline & Mean & s.d. & Mean & s.d. & & \\
\hline Board membership in the holding & .84 & .38 & .32 & .48 & $3.94 * * *$ & 39 \\
\hline Board position at one of the affiliates & .89 & .32 & .68 & .48 & 1.71 & 37 \\
\hline $\begin{array}{l}\text { Executive positions at the holding } \\
\text { headquarters }\end{array}$ & .47 & .51 & .50 & .51 & -.164 & 39 \\
\hline Executive position in the affilliates & 0 & 0 & .41 & .50 & $-3.81 * * *$ & 21 \\
\hline $\begin{array}{l}\text { Executive at the holding or at the affiliate } \\
\text { level }\end{array}$ & .47 & .51 & .91 & .30 & $-3.27 * *$ & 28 \\
\hline $\begin{array}{l}\text { Percentage of board membership in quoted } \\
\text { affiliates }\end{array}$ & .34 & .32 & .12 & .17 & $2.72 *$ & 26 \\
\hline
\end{tabular}

$* \mathrm{p}<0.05 ; * * \mathrm{p}<0.01 ; * * * \mathrm{p}<0.0$

Table 3 displays results for the international experience and educational characteristics of the family members in the four sub-samples. Table 3 a includes results for the three business groups in which the first and second generations are in power. Due to the small sample size in this sub-sample, no statistical test is performed for variables that are coded into two categories. Only the differences in education level between the first and second generations are tested by a Mann Whitney U test. The results show that in the young business groups, the second generation family members have significantly higher levels of education than do the founder's generation for both measures of education level. The family members from the founders' generation have 9 years of formal education after elementary school and on average have a high school degree whereas the second generation family members have 13.36 years of formal education and on average the equivalent of a graduate degree (3.83) according to the categorical measure. None of the first generation family members have a graduate degree whereas $83 \%$ of the second generation family members do.

Only $25 \%$ of the family members from the founder's generation had international experience; none of them studied abroad and only one of them worked abroad. Almost all the second generation family members, on the other hand, obtained a degree from abroad (92\%) and half of them have a work experience abroad. 
The founder generation family members have all worked only within their family business except for one, whereas $50 \%$ of the second generation family members have work experience in other firms.

Table 3a

International Experience and Education Level of
Family Members in Young Business Groups

\begin{tabular}{|c|c|c|c|c|c|}
\hline & \multicolumn{4}{|c|}{ Young business groups } & \multirow{3}{*}{$\mathrm{z}$ value } \\
\hline & \multicolumn{2}{|c|}{$\begin{array}{l}\text { First generation } \\
(N=4)\end{array}$} & \multicolumn{2}{|c|}{$\begin{array}{c}\begin{array}{c}\text { Second generation } \\
(\mathrm{N}=12)\end{array} \\
\end{array}$} & \\
\hline & Mean & s.d. & Mean & s.d. & \\
\hline Study abroad & 0 & 0 & .92 & .29 & n.a. \\
\hline Work abroad & .25 & .50 & .50 & .52 & n.a. \\
\hline $\begin{array}{l}\text { International experience } \\
\text { (study or work) }\end{array}$ & .25 & .50 & .92 & .29 & n.a. \\
\hline Work experience in other firms & 0.25 & .50 & .50 & .52 & n.a. \\
\hline Level of education & 2.00 & 1.16 & 3.83 & .39 & $-3.099 * *$ \\
\hline Graduate degree & 0 & 0 & .83 & .39 & n.a. \\
\hline $\begin{array}{l}\text { Years of education after elementary } \\
\text { school }\end{array}$ & 9 & 2.58 & 13.36 & 1.36 & $-2.64 * *$ \\
\hline
\end{tabular}

$* \mathrm{p}<0.05 ; * * \mathrm{p}<0.01 ; * * * \mathrm{p}<0.001$

T-test results for the five business groups, in which the second and third generation family members are in power, are displayed in Table $3 b$. The third generation family members have significantly higher levels of education than do the second generation for both measures of education level. The family members from the second generation have 9.44 years of formal education after elementary school and on average have a degree (2.67) that is in between a high school and a university degree according to the categorical measure. The third generation family members, on the other hand, have 12.33 years of formal education after elementary school and on average have a higher level of education than a university degree (3.33). A significantly higher percentage of third generation family members $(3.33 \%)$ have a graduate degree than do the second generation family members (17\%).

In terms of international experience, a significantly higher percentage of third generation family members $(43 \%)$ have international work experience than do the second generation family members $(11 \%)$. However, the results are not significant for the second measure of international experience, study abroad. A higher percentage of third generation family members (70\%) have obtained a degree abroad than have second generation family members (44\%), but the difference is not statistically significant.

None of the second generation family members have work experience outside their family business group whereas one-fourth of the family members from the third generation have worked in companies unaffiliated with their group. 
Table 3b

\section{T-test Results for International Experience and Education Level of} Family Members in Old Business Groups

\begin{tabular}{|c|c|c|c|c|c|c|}
\hline & \multicolumn{4}{|c|}{ Old business groups } & \multirow[b]{3}{*}{ t } & \multirow[b]{3}{*}{ df } \\
\hline & \multicolumn{2}{|c|}{$\begin{array}{c}\text { Second generation } \\
(\mathrm{N}=18)\end{array}$} & \multicolumn{2}{|c|}{$\begin{array}{l}\text { Third generation } \\
(\mathbf{N}=\mathbf{2 2})\end{array}$} & & \\
\hline & Mean & s.d. & Mean & s.d. & & \\
\hline Study abroad & .44 & .51 & .70 & .47 & -1.61 & 36 \\
\hline Work abroad & .11 & .32 & .43 & .51 & $-2.36^{*}$ & 34 \\
\hline $\begin{array}{l}\text { International experience } \\
\text { (study or work) }\end{array}$ & .50 & .51 & .76 & .44 & $-1,70$ & 34 \\
\hline Work experience in other firms & 0 & 0 & .26 & .45 & $-2.54 *$ & 18 \\
\hline Level of education & 2.67 & 1.09 & 3.33 & .47 & $-2.29 *$ & 23 \\
\hline Graduate degree & .17 & .38 & .35 & .49 & -1.29 & 35 \\
\hline $\begin{array}{l}\text { Years of education after elementary } \\
\text { school }\end{array}$ & 9.44 & 4.34 & 12.33 & 1.68 & $-2.63 *$ & 22 \\
\hline
\end{tabular}

$* \mathrm{p}<0.05 ; * * \mathrm{p}<0.01 ; * * * \mathrm{p}<0.001$

Table 4 presents a categorical distribution of high schools attended by old and young generation family members in the four sub-samples. In the young business groups, half of the first generation family members went to prestigious high schools in Turkey and half of them went to schools that are included in the 'other' category. More than $80 \%$ of the second generation family members, on the other hand, went to prestigious high schools in Turkey and 10\% studied in high schools abroad.

In the old business groups, approximately $50 \%$ of the second generation family members studied in prestigious high schools in Turkey. The second generation family members in one of the old business groups do not have a high school degree. Nearly one-fifth of the third generation family members, on the other hand, studied in high school abroad, and around $80 \%$ went to prestigious high schools in Turkey.

In the young business groups, none of the first generation family members had undergraduate study abroad while two-thirds of the second generation family members did. In the old business groups, on the other hand, $28 \%$ of the second generation family members and $65 \%$ of the third generation family members obtained their undergraduate degrees abroad. 
Table 4

High School Attendance of Family Members

\begin{tabular}{ccccc}
\hline & \multicolumn{4}{c}{ Young business groups } \\
\cline { 2 - 5 } & Studied abroad & $\begin{array}{c}\text { Prestigious high schools } \\
\text { in Turkey }\end{array}$ & Other & $\begin{array}{c}\text { No high } \\
\text { school degree }\end{array}$ \\
\hline First generation & 0 & .50 & .50 & 0 \\
Second generation & .091 & .82 & .091 & 0 \\
\hline & Studied abroad & $\begin{array}{c}\text { Prestigious high schools } \\
\text { in Turkey }\end{array}$ & Other & $\begin{array}{c}\text { No high } \\
\text { school degree }\end{array}$ \\
\cline { 2 - 5 } & 0 & .526 & .368 & .105 \\
Second generation & .167 & .778 & .056 & 0 \\
\hline Third generation & & Old business groups & \\
\hline
\end{tabular}

\section{DISCUSSION AND CONCLUSION}

In the sample, three family business groups are relatively young. Their founders are alive and the business is run by the first and second generation family members. Previous studies show that the transfer of power from the first to the second generation rarely takes place when the founder is still alive (e.g. Barnes and Hershon, 1994). The important influence of founders on the business during and after their term is well established in family business literature (Sharma, 2004). In one of these groups, the founder is actively involved in the business with many executive and board membership positions, while in the other two groups, the founders are too old to hold many positions and they seem to be involved in the business just to safeguard the group activities. In the other five groups, the average number of family members involved in the business is larger since these groups are run by the second and third generations. They may be considered as being at the cousins' consortium stage since the ownership and management in these groups are spread also among cousins (Lansberg et al, 1997).

Conflict in the organization is less when the founder is still involved in the business (Davis and Harveston, 1999) since the founder's shadow may provide a clear set of values and direction for the business (Sonfield and Lussier, 2004). The founder-owner is said to play a key role in creating harmony in the family business by acting as family arbiter (Kets de Vries and Miller, 1993). Conflict and power struggles are more likely to increase when the second and third generations are in power because it becomes more difficult to maintain cohesiveness once the generations are spread out (Kets de Vries and Miller, 1993). As familial distance increases, the consensus of the family may become diluted (Gersick et al., 1997) because sometimes cousins may not share a long history of prior interaction and this may reduce trust between extended family members (Ensley and Pearson, 2005). At the cousin consortium stage, each branch of the family has its own agenda that at times conflicts with the others (Gersick et al., 1997). Rivalries among family members may arise from jealousy over each other's positions (Zahra et al., 2007). In Group 2, for example, some cousins have recently sold their shares to the public and formed their own business groups whose activities do not overlap 
with the traditional sectors of the original group. However, the extended family is still the dominant shareholder in this group. At the end of the research period, one of the cousins in Group 7 also became detached from the family business by selling shares to his/her father and relinquishing all the executive and board membership positions within the group. Speculations on such disputes or power struggles among extended family members of these leading FBGs at times appear in the media, but there is no dissolution of family control in any of these groups yet. The majority ownership and key managerial position are still held by the families.

The role of the family in the governance of the groups seems to be long-term oriented and much more inclusive than ownership control of the groups. Family members from both generations and sexes are involved in the governance and management of FBGs as board members and/or executives at both group and affiliate levels. This may suggest the willingness of the family to continue to rule and manage the group with its own members in order to conserve and expand the family fortune. Passing on possessions and name to future generations is a human tradition that leads the family to seek continuity in the family business (Barnes and Hershon, 1994).

It is also notable that the percentage of female family members in the sample is very high, especially when one considers the male dominance in the salaried managers category in prominent business groups (Üsdiken and Yıldırım, 2007) or general managers in the largest industrial companies in Turkey (Yamak, 1998). Concern of the family to rule and manage the group may be one of the reasons for the high percentage of female family members since there is a limited or in some cases insufficient male supply from the family. For example, in Group 3 the founder does not have a son and only one of the grooms is included in the business and the other three have their own family businesses. Previous research on stand-alone Spanish family businesses also found that daughters were considered as successors when they were the first born child or when there was no male descendent (GarciaAlvarez et al., 2002). A harmonious relationship between fathers and their daughters may also explain the high percentage of females in the sample. In Group 6, for example, the two daughters rather than the son of the founder have been working in the family business because the son could not get along well with his father; he has no involvement in the family business. Family business literature suggests that power and control issues are likely to arise between father and son whereas fathers and daughters have a more harmonious relationship since daughters assume caretaker roles for the business and the father (Dumas, 1989).

As expected, the younger generation family members in the sample have more novel assignments. Additional data showed that these novel assignments included working at foreign subsidiaries of the business group, managing business lines that are new to the group, and working in divisions such as new business development. For example, two grandsons of the founder in Group 4 have been working in the construction sector in Russia and another grandson in Group 8 worked in a foreign branch of the holding bank. It is also quite common for the young generation family members to work in sectors that are relatively new for the group. For example, one of the grandsons of the founder in Group 1 has been head of the information technology business line and another grandson in Group 7 started his career in real estate which is a very new business line for the group. In some of the cases, divisions such as new business development also accommodate new generation family members. Business lines or functional areas, in which senior family members do not have expertise, are managed by younger generation family members who are better equipped for these novel assignments. 
The family seems to recognize the importance of education and international experience as a resource for the development of its family members. In terms of educational attainment, the average educational level of family members corresponds to a university degree. This is a high average considering that in Turkey only $8.71 \%$ of the population who are above 25 years old, have an undergraduate degree in 2008 (tuik.gov.tr). In terms of the average number of years in formal education after the five-year compulsory elementary school, owner families of the leading business groups score also much higher (11.27) than those of the average of family CEOs (8.94) in a random sample of mostly stand-alone family businesses in all regions of Turkey (Yıldırım-Öktem and Yamak, 2008).

An analysis is done to check whether there are differences between the two sexes in terms of formal education. It is found that male family members in the sample have more formal education than their female counterparts; however this difference is not statistically significant. The inclusion of welleducated family members from both sexes might have been necessary for sustaining family control, particularly for groups that had an insufficient male supply.

The results show that almost $70 \%$ of the sample studied in prestigious high schools in Turkey; the majority of them went to foreign private high schools. Almost half of the family members, on the other hand, had undergraduate study abroad. These findings may also be supportive of the importance that prominent families give to formal education, in line with what was also concluded from the interviews of Buğra (1994) with family members.

The percentage of family members with international work experience is high (70\%). However, family members have gained interational experience mostly through studying abroad (60\%). The percentage of family members with international work experience is only one-third and most of them worked abroad in one of the foreign subsidiaries of the business group. Only nine family members worked abroad in a company that was not affiliated with the business group. An additional analysis shows that there is a significant difference between the percentages of male and female family members who have international experience. A significantly higher percentage of male family members have international experience than female family members. It seems that families give importance to formal education of both sexes; however they are reluctant to send female members abroad. This may be explained by the conservative character of Turkish culture.

Gaining work experience outside the group is not very common for family members (23\%). This low ratio shows that the family members' tenure within the group is high and experience is mostly gained by working in group affiliates or at the headquarters. This is perhaps due to the particular importance of tacit knowledge in family businesses. Family members may prefer to start working within the group early in order to gain the tacit knowledge which is difficult to share and can best be transmitted through informal forms of direct exposure and common experiences such as frequent face-to-face meetings and shared beliefs and values (Zahra et al., 2007).

\section{Business Involvement of the Family Members in the Four Sub-samples}

In the young business groups, only one of the founders is actively involved in the business with many executive and board membership positions, while in the other two groups the founders are too old. However, all of them have executive positions at the central management unit, mostly through membership in the executive committee of the group. This is an indicator of the founders' reluctance 
to lose power and to detach themselves from the family business. In these business groups, a higher percentage of the founder generation family members are also represented in boards of listed firms than are the second generation family members. The second generation in these groups is involved at all levels both as board directors and executives, probably to fill in the seats at key positions where the founders' generation cannot be present due to old age.

In the old business groups, however, a significantly higher percentage of second generation family members have board memberships at the holding than do the third generation family members. This may be explained by the formers' social capital, group-wide experience and social standing. The younger generation family members, on the other hand, mostly perform executive roles within the group, and a significantly higher percentage of them are executives at the affiliate level. This may be due to their young age, higher education level and exposure to different experiences. The result is significant only for affiliate level executive positions probably because affiliates are training grounds for the young generation family members who obtain group-level positions after accumulating more experience and social capital. It may also be that control of a large and diversified group structure necessitates familial involvement at the managerial level of affiliates.

\section{Background Characteristics of the Family Members in the Four Sub-samples}

When the four sub-samples are considered, in both the younger and older business groups, the younger generation family members have significantly higher levels of education than do the old generation family members. As expected, the result is more significant for the difference between the founder generation and the second generation than between the second and third generation family members. It may be because the founders' generation concentrated on expanding the group while the latter generations were both raised in more favorable socio-economic circumstances and were prepared to take part in the governance of the group. In line with this finding, in the old business groups the difference between the second and the third generation is insignificant for study abroad and graduate study dimensions. In the young business groups, on the other hand, none of the first generation family members has a graduate degree or a study abroad experience whereas the percentage of second generation family members with study abroad experience and graduate degrees is quite high. It seems that having a graduate degree and studying abroad become common starting with the second generation.

There is a significant difference, however, in international work experience between the second and third generation family members in the old business groups. Moreover, a majority of the third generation family members gained international work experience in firms not affiliated with their business groups whereas the second generation family members worked in foreign subsidiaries of their family businesses. None of the second generation family members has work experience outside their groups whereas one-fourth of the third generation family members do. Although the difference is significant, it can be said that having work experience outside the group is still not very common. This shows also that the third generation family members tend to start gaining experience within the group after finishing their formal education. There are similar findings for stand-alone family businesses in developed countries. For example, Garcia-Alvarez et al. (2002) found that most prospective successors returned to the family business after completing their formal education. Goldberg (1996) found that the conventional thinking of having work experience outside the family business was being transformed by an increasing number of young generation family members having higher educational attainments. 
There may be several reasons for not delaying entry into the group. First, group affiliates are seen as training grounds for young family members (Buğra, 1994). As mentioned in earlier sections, the FBGs are large organizations with many affiliated firms operating in various industries. The form allows the young generation family members to get an overview of the business by working in the headquarters, working in one of the affiliates according to its relative importance to the group/their area of interest, or even entering a new area of business according their interest/expertise after gaining some experience. Second, the young family members may be willing to start gaining firm/group specific knowledge via the mentoring of senior family members or trusted non-kin managers. Such mentoring is not likely to be provided in companies not affiliated with the group. Early exposure makes the transfer of this tacit knowledge easier since he/she starts becoming familiar with the nature of business and gaining specific capabilities for the business (Cabrera-Suarez et al., 2001). Third, relations within the nuclear family such as the authority of the eldest brother may be a norm, but at the cousins' consortium stage one may expect more competition and power struggles in the extended family, particularly among cousins of a similar age. For this reason potential successors may prefer to start early gaining tenure within the group which is quite important for promotion and keeping key positions.

In the young business groups, there is a bigger difference between the first and the young generation family members in obtaining graduate degrees and/or study/work abroad. In contrast to the second generation family members in the old business groups, the second generation family members in the young business groups do have international work experience in firms not affiliated to business groups. Likewise, a percentage of the second generation family members with work experience in other firms is also high. Since these business groups are relatively younger, there may be a more modernization effect on the second generation of these groups.

In both the young and the old business groups, the high school and undergraduate background differs between the younger and the older generation family members. In both sub-samples, the younger generation family members went to more prestigious high schools. A higher percentage of them went to prestigious high schools in Turkey whereas a substantial percentage of the older generation family members went to high schools that are in the 'other' category. As far as the undergraduate background, a higher percentage of the younger generation family members studied abroad. The results for the older generation family members in both sub-samples are comparable to the average education level of top managers in the list of the first 500 companies in Turkey. Yamak (1998) found that in 1992, $96.1 \%$ of the top managers had at least undergraduate degrees, and the average number of years after elementary school was 10.6 . Around $35 \%$ of the top management team in these large organizations also had graduate degrees. This suggests that the gap between the education levels of the professional managers in large organizations and the prominent family members is not big.

\section{LIMITATIONS AND SUGGESTIONS FOR FUTURE RESEARCH}

This article has analyzed the way the senior and the young generation family members share the governance and management of the group and their background characteristics. The article is limited in that it only includes the family members who are involved in the business. Additional data about the family will be needed to extend the analyses offered here. Another limitation of the study is the small sample size. Since comparisons across generations required dividing the sample into four sub-

samples, the size of some of the sub-samples became particularly small. The study can be expanded by including other leading Turkish business groups that are run by two consecutive generations. The 
percentage of family members involved in the family business, the reasons to pursue a career in and outside the family business, and the inter-generational differences within the whole family may be some of the topics that can be explored in future research. Finally, a narrative approach can make important contributions to the study (Hamilton, 2006). Family members from both generations might be interviewed to gain a deeper understanding about power distribution, succession process and roles that are adopted by the senior and the younger generation family members.

\section{NOTE}

1. Group 7 is run by the second and third generations, but in Table I it appears to be younger than the five business groups that are run by the first and second generation family members. This is due to the measurement of age, which was calculated based on the year the first incorporation within the group was established. Although rudimentary activities of the group date back to the early 1950s, its first incorporation was in 1980 .

\section{REFERENCES}

Adler, P.S. and Kwon, S.W. (2002). "Social Capital: Prospects for a New Concept," Academy of Management Review, 27: 17-40.

Aulakh, P.S. and Katobe, M. (2008). "Institutional Changes and Organizational Transformation in Developing Economies,” Journal of International Management, 14: 209-216.

Barnes, L.B. and Hershon, S.A. (1994). "Transferring Business in the Family Business," Family Business Review, 7: 377-392.

Buğra, A. (1994). "The Turkish Holding Company as a Social Institution,” in A. Buğra (ed.), State and Business in Modern Turkey. A Comparative Study: 171-224. New York: State University of New York Press.

Cabrera-Suarez, K., De Saa-Perez, P., Garcia-Almeida, D. (2001). "The Succession Process from a Resource- and Knowledge-based View of the Family Firm," Family Business Review, 14: 37-46.

Carney, M. (2008). Asian Business Groups: Context, Governance and Performance. UK: Chandos Publishing.

Caselli, F. and Gennaiola, N. (2003). “Dynastic Management,” NBER Working Paper 9442.

Chandler, A.D. (1977). The Invisible Hand: The Managerial Revolution in American Business. Cambridge, MA: Harvard University Press.

Chung, C. (2003). "Managerial Structures of Business Groups in Taiwan: The Inner Circle System and Its Social Organization,” Developing Economies, 41: 37-64.

Chung, C.N. and Luo, X. (2008). "Human Agents, Contexts and Institutional Change: The Decline of Family in the Leadership of Business Groups," Organization Science, 19: 124-142. 
Çolpan, A.M. (2010). "Business Groups in Turkey," in A.M. Çolpan and T. Hikino (eds.), Oxford Handbook of Business Groups. UK: Oxford University Press.

Çolpan, A.M. and Hikino, T. (2008). “Türkiye'nin Büyük Şirketler Kesiminde İşletme Gruplarının İktisadi Rolü ve Çeşitlendirme Stratejileri,” Yönetim Araştırması Dergisi, 8: 23-58.

Daily, C.M. and Johnson, J.I. (1997). “CEO Power,” Journal of Management, 23: 97-117.

Davis, P.S. and Harveston, P.D. (1999). "In the Founder's Shadow: Conflict in the Family Firm," Family Business Review, 12: 311-323.

Dieleman, M. and Sachs, W.M. (2008). "Coevolution of Institutions in Emerging Economies: How the Salim Group Morphed into an Institution of Suharto's Crony Regime," Journal of Management Studies, 45: 1274-1300.

Dumas, C. (1989). "Understanding of Father-Daughter and Father-Son Dyads in Family-owned Businesses," Family Business Review, 2: 31-46.

Ensley M.D. and Pearson, A.W. (2005). "An Exploratory Comparison of the Behavioral Dynamics of Top Management Teams in New Ventures: Cohesion, Conflict, Potency, and Consensus," Entrepreneurship Theory and Practice, 29: 267-284.

Finkelstein, S. (1992). "Power in Top Management Teams: Dimensions, Measurement, and Validation," Academy of Management Journals, 35: 505-538.

Finkelstein, S. and Hambrick, D. (1996). Strategic Leadership: Top Executives and Their Effects on Organizations. West Publishing Company, St Paul, MN.

Fisman, R. and Khanna, T. (2004). "Facilitating Development: The Role of Business Groups," World Development, 32: 609-628.

Garcia-Alvarez, E., Lopez-Sintas, J., and Gonzalvo, P.S. (2002). "Socialization Patterns of Successors in First- to Second-generation Family Businesses," Family Business Review, 15: 189-204.

Gersick K.E., Davis, J., Hampton, M.M., and Lansberg, I. (1997). Generation to Generation: Life Cycles of the Family Business. Boston, MA: Harvard Business School Press.

Gilding, M. (2005). "Families and Fortunes: Accumulation, Management Succession and Inheritance in Wealthy Families," Journal of Sociology, 41: 29-45.

Gittell, R. and Vidal, A. (1998). Community Organizing: Building Social Capital as a Development Strategy. Thousand Oaks, CA: Sage.

Goldberg, S.D. (1996). "Effective Successors in Family-Owned Businesses: Significant Elements," Family Business Review, 9: 185-197. 
Gönenç H., Kan, O.B., and Karadağl1, E.C. (2007). "Business Groups and Internal Capital Markets," Emerging Market Finance and Trade, 43: 63-81.

Gökşen, N.S. and Üsdiken, B. (2001). "Uniformity and Diversity in Turkish Business Groups: Effects of Scale and Time of Founding," British Journal of Management, 12: 325-340.

Granovetter, M. (1995). “Coase Revisited: Business Groups in the Modern Economy,” Industrial Corporate Change, 4: 93-140.

Guillen, M.F. (2000). “Business Groups in Emerging Economies: A Resource-based View,” Academy of Management Journal, 43: 362-380.

Hambrick, D.C. (1981). "Environment, Strategy, and Power within Top Management Teams," Administrative Science Quarterly, 26: 253-276.

Hamilton, E. (2006). "Whose Story is it Anyway? Narrative Accounts of the Role of Women in Founding and Establishing Family Businesses," International Small Business Journal, 24: 253-271.

Hamilton, G.G. and Biggart, N.W. (1988). "Market, Culture and Authority: A Comparative Analysis of Management and Organization in the Far East," American Journal of Sociology, 94: 52-94.

Harvey, M. and Evans, R. (1995). "Life After Succession in the Family Business. Is it Really the End of Problems?," Family Business Review, 8: 3-16.

Hofstede, G. (1994). “Management Scientists are Human,” Management Science, 40: 4-13.

Hoskisson, R.E., Eden L., Ming-Lau, C., and Wright, M. (2000). "Strategy in Emerging Economies," Academy of Management Journal, 43: 249-267.

Hundt, D. (2005). “A Legitimate Paradox: Neo Liberal Reform and the Return of the State in Korea," Journal of Development Studies, 41: 242-260.

Jang, H. and Kim, J. (2002). "Nascent Stages of Corporate Governance in an Emerging Market: Regulatory Change, Shareholder Activism and Samsung Electronics," Corporate Governance, 10: 94-105.

Khanna, T. and Yafeh, Y. (2007). "Business Groups in Emerging Markets: Paragons or Parasites?," Journal of Economic Literature, 45: 331-372.

Kets de Vries, M.F.R. and Miller, D. (1993). "The Dynamics of Family-Controlled Firms," Organizational Dynamics, 21: 59-71.

Kim, E.M. (1996). "The Industrial Organization and Growth of the Korean Chaebol: Integrating Development and Organizational Theories," in G.G. Hamilton (ed.), Asian Business Networks: 231250. Berlin: De Gruyter. 
Kim, S.J. (2004). “Bailout and Conglomeration,” Journal of Financial Economics, 71: 315-347.

Kogut, B. and Zander U. (1992). "Knowledge of the Firm: Combinative Capabilities, and the Replication of Technology," Organization Science, 3: 383-97.

Lansberg, I. (1988). “The Succession Conspiracy,” Family Business Review, 1: 119-143.

Lansberg, I., Gersick, K.E., Davis, J.A., and McCollom, M. (1997). Generation to Generation. Cambridge, MA: Harvard Business School Press.

Lee, S.M. and Yoo, S. (1987). "The K-Type Management: A Driving Force of Korean Prosperity," Management International Review, 27: 68-77.

Lee, D.S., Lim, G.H., and Lim, W.S. (2003). "Family Business Succession: Appropriation Risk and Choice of Successor," Academy of Management Review, 28: 657-666.

Litz, R.A. (1995). “The Family Business: Toward Definitional Clarity,” Family Business Review, 8: 71-81.

Miller, D. and Le Breton-Miller, I. (2005). Managing for the Long-Run. Lessons in Competitive Advantage of Great Family Businesses. USA: Harvard Business School Press.

Morck, R., Wolfenzon, D., and Yeung, B. (2005). "Corporate Governance, Economic Entrenchment, and Growth,” Journal of Economic Literature, 13: 655-720.

Nahapiet, J. and Ghoshal, S. (1998). "Social Capital, Intellectual Capital, and the Organizational Advantage," Academy of Management Review, 23: 242-266.

Paşa, F.S., Kabasakal, H., and Bodur, M. (2001). "Society, Organizations and Leadership in Turkey," Applied Psychology: An International Review, 50: 559-589.

Selekler-Gökşen, N. and Yıldırım-Öktem, Ö. (2009). “Countervailing Institutional Forces: Corporate Governance in Emerging Economies,” Journal of Governance and Management, 13: 193-213.

Sharma, P. (2004). "An Overview of the Field of Family Business Studies: Current Status and Directions for the Future," Family Business Review, 17: 1-36.

Shin, Y.K. (1998). "The Traits and Leadership Styles of CEOs in Korean Companies," International Studies of Management and Organization, 28: 40-48.

Shin, E.H. and Chin, S.K. (1989). "Social Affinity among Top Managerial Executives of Large Corporations in Korea," Social Forum, 4: 3-26.

Siegel, J. (2007). "Contingent Political Capital and International Alliances: Evidence from South Korea,” Administrative Science Quarterly, 52: 621-666. 
Sonfield, M.C. and Lussier, R.N. (2004). "First, Second, and Third Generation Family Firms: A Comparison," Family Business Review, 17: 189-202.

Steier, L. (2001). "Next Generation Entrepreneurs and Succession: An Exploratory Study of Modes and Means of Managing Social Capital," Family Business Review, 14: 259-276.

Suehiro, A. (1993). "Family Business Reassessed: Corporate Structure and Late-Starting Industrialization in Thailand," The Developing Economies, 31: 378-407.

Tsui-Auch, L.S. (2004). “The Profesonally Managed Family Ruled Enterprise: Ethnic Chinese Business in Singapore," Journal of Management Studies, 41: 696-723.

Üsdiken, B. (2008). “Türkiye'de İşletme Grupları: Özel Sayı'ya Giriş,” Yönetim Araştırmaları Dergisi, 8: 5-21.

-----, (2010). "The Kin and the Professional: Top Leadership in Family Business Groups," in A.M. Çolpan and T. Hikino (eds.), Oxford Handbook of Business Groups. UK: Oxford University Press.

Üsdiken, B. and Yıldırım, Ö. (2007). "National Business Systems and Educational Backgrounds of Salaried Top Managers: The Case of Turkish Family Business Groups," Conference Proceedings of 23rd EGOS Colloquium, Vienna.

Üsdiken, B. and Yıldırım-Öktem, Ö. (2008). "Kurumsal Ortamda Değişim ve Büyük Aile Holdingleri Bünyesindeki Şirketlerin Yönetim Kurullarında ‘İcrada Görevli Olmayan' ve ‘Bağımsız' Üyeler,” Amme İdaresi Dergisi, 41: 43-71.

Wan, W.P. (2005). "Country Resource Environments, Firm Capabilities, and Corporate Diversification Strategies," Journal of Management Studies, 42: 161-182.

www.tuik.gov.tr

Yamak, S. (1998). "Education Level of Managerial Elites in Turkey: How Has It Evolved from 80's to 90's?," Amme İdaresi Dergisi, 31: 65-78.

Yamak, S. and Üsdiken, B. (2006). "Economic Liberalization and the Antecedents of Top Management Teams: Evidence from Turkish 'Big' Business,” British Journal of Management, 17(3): 177-194.

Yıldırım-Öktem, Ö. and Selekler-Gökşen, N. (2010). “Kurumsal Baskılar ve Aile Kontrolündeki Şirket Gruplarına Bağlı Şirketlerin Yönetim Kurulu Kompozisyonlarındaki Değişim,” 4. Aile İşletmeleri Kongre Kitab1, Istanbul.

Y1ldırım-Öktem, Ö. and Yamak, S. (2008). "Facets of CEO Power in Family Firms," EURAM (European Academy of Management) Best Papers Proceedings, Ljubljana, Slovenia.

Yıldırım, Ö. and Üsdiken, B. (2005). "Board of Director in Firms within Family Business Groups: Evidence from Turkish Holding Companies," $21^{\text {st }}$ EGOS Colloquium, Berlin, Germany. 
Y1ldırım-Öktem, Ö. and Üsdiken, B., (2010). "Contingencies versus External Pressure: Professionalization in Boards of Firms Affiliated to Family Business Groups in Late Industrializing Countries," British Journal of Management, 21: 115-130.

Yiu, D.W., Lu, Y., Bruton, G.D., and Hoskisson, R.E. (2007). “Business Groups: An Integrated Model to Focus Future Research," Journal of Management Studies, 44: 1551-1579.

Yurtoğlu, B.B. (2000). "Ownership, Control and Performance of Turkish Listed Firms," Journal of Applied Economics and Economic Policy, 27: 193-222.

Zahra, S.A., Donald, A.N., and Larraneta, B. (2007). "Knowledge Sharing and Technological Capabilities: The Moderating Role of Family Involvement," Journal of Business Research, 60: 10701079. 